"Mircea cel Batran" Naval Academy Scientific Bulletin, Volume XIX - 2016 - Issue 1

Published by "Mircea cel Batran" Naval Academy Press, Constanta, Romania /l The journal is indexed in:

PROQUEST / DOAJ / DRJI / JOURNAL INDEX / I2OR / SCIENCE LIBRARY INDEX / Google Scholar / Crossref /

Academic Keys / ROAD Open Access / OAJI / Academic Resources / Scientific Indexing Services / SCIPIO

\title{
A TECHNOLOGICAL ASSESSMENT OFTHE WAVE ENERGY CONVERTER
}

\author{
K. Turgut GÜRSEL ${ }^{1}$ \\ Deniz ÜNSALAN² \\ Gökdeniz NEŞER ${ }^{3}$ \\ Mesut TANER ${ }^{4}$ \\ Erkin ALTUNSARAY ${ }^{5}$ \\ Mehmet ÖNAL ${ }^{6}$ \\ 1,2,3,4,5,6Institute of Marine Sciences and Technology, Department of Naval Architect, Dokuz Eylül University, \\ Inciraltı - 35340 Izmir, Turkey(Corresponding author, e-mail: turgut.gursel@deu.edu.tr)
}

\begin{abstract}
Global demand for energy increases annually, at the same time as the demand for carbon-free, sulphur-free and NOx-free energy resources grows considerably. This is manifested in the research for newer sources like biomass and shale gas as well as the renewable energy resources like solar, wind, geothermal and hydraulic energy.

Wave energy is also a form of renewable energy which has not fully been exploited technically and economically. However, it is beyond doubt that the demand for wave energy will soon increase as fossil energy resources are depleted and environmental concerns gain more importance.

The electrical energy to be supplied to the grid shall be produced from the wave energy whose conversion can basically be carried out by three classes of systems:

$i$. Systems that exploit the motions or shape deformations of their mechanisms involved, being driven by the energy of waves passing.

ii. Systems that exploit the weight of the seawater stored in a reservoir or the changes of water pressure by the oscillations of wave height,

iii. Systems that convert the wave motions into air flow.
\end{abstract}

This study is aimed for a general survey of the systems and classification of the wave energy converters based on their types and functionality, as well as investigating their state-of-the-art.

Keywords: Wave energy, wave converter, type of converter, assessment of converter.

\section{INTRODUCTION}

Global demand for energy increases annually, whereas the demand for carbon-free, sulphur-free and $\mathrm{NO}_{x}$-free energy resources grows considerably. Nowadays there is a great need for the research for newer sources like biomass and shale gas as well as the renewable energy resources like solar, wind, geothermal and hydraulic energy. Scientists and engineers as well as leaders in renewable energy sector have the thought that wave energy is also a form of renewable energy which has not fully been exploited technically and economically.

The wind generated by solar energy creates socalled wind-waves consisting of huge amounts of energy. The total theoretical wave power resource in the oceans is estimated between 1-10 TW, whilst the average electrical power consumption of the world accounts for approx. 2 TW.

Wave - Wind Relations and Wave Characteristics
The wind velocity profile expands over several kilometres as seen in Figure 1, thus a wind turbine and/or farm exploits only a tiny sublayer of that. In contradiction to wind, most of the wave energy flux is concentrated near the sea surface; hence a wave farm at the sea surface can absorb a large part of the wave energy flux (Fig. 1 and 2).

Waves are formed by winds blowing over the sea and ocean surface, which make the water particles adopt circular motions. Wave energy occurs due to the movements of these water particles near the surface of the sea. This motion carries kinetic energy, the amount of which depends on the speed, duration and unchanged direction of the wind, the length of sea, over which it blows (fetch), the water depth, sea bed conditions and interactions with the tides. The stronger the wind and the longer the distance over which it blows, the larger the waves and the more energy they carry. This energy can be harvested from waves in terms of the following characteristics: 


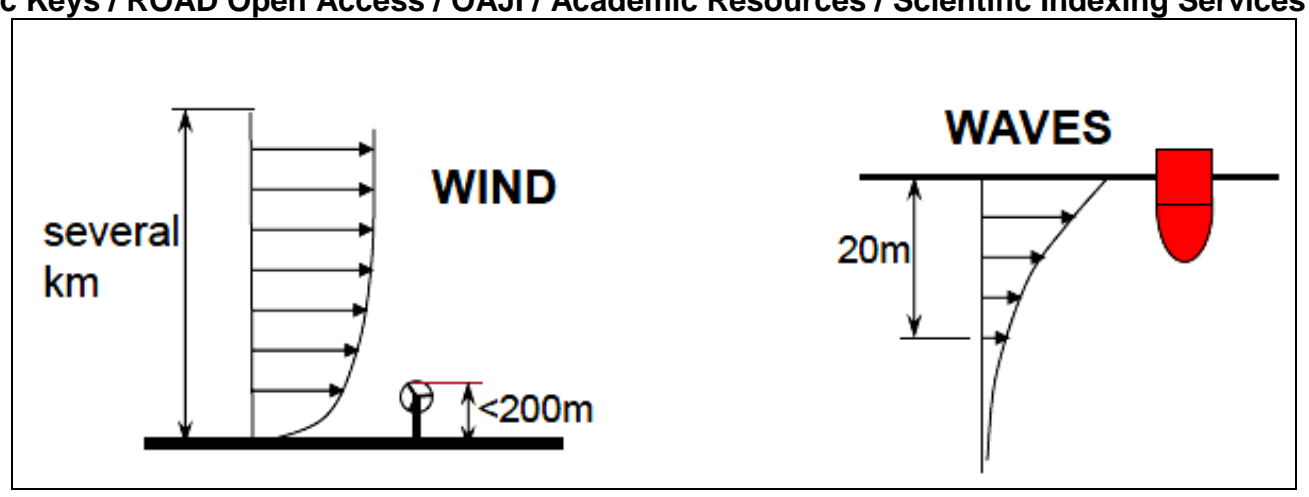

Figure 1. Comparison of the velocity profiles of the wave and wind [1]

a) The waves possess the potential energy due to gravity, and so the movements of the water from a higher to a lower potential energy position yield its share, and

b) Additionally they have the kinetic energy produced by the actual movement of the waves and create the other share in wave energy.

For exploiting wind energy, wind turbines are worldwide deployed, whereat a major change and/or difference in the design and manufacturing of the wind turbines is worldwide not visible. However the state of the art in wave energy systems is very different, since many various wave energy converters (WECs) were designed and manufactured as prototypes due to complex interactions between coastal- near shore offshore waves and devices [1-3].

In exploiting wave energy, the aim always is to extract energy from the ocean and/or sea waves as much efficiently and safely as possible with the cheapest investment and operating costs as well as with producing maximum economic return through so-called WECs of different types. However, it is technically and economically an uncontroversial problem to meet the expectations to design and produce a commercially viable wave energy converter (WEC),because the following principle design challenges for WECs should be overcome:

i. Ocean renewable energy technologies tend to be very intermittent in their power output if the electric energy obtained by these technologies are transmitted and synchronized in consumer locations. The WECs can extract significant amounts of energy when the waves encounter them directly and continuously, which however is usually not always the case. As a result, the traditional wave energy techniques do not produce energy continuously. ii. It is still unable to economically store wave power.

iii. Wave energy technologies produce electricity at a very low frequency which does not match high voltage grid connections on land.

iv. Survivability of the WECs in storm conditions has been a key obstacle of ocean technologies in the past, presence and near future.

Most sea-based energy generating technologies are hampered by several factors such as design-based weakness and/or construction-based shortcomings. As a result, many of the WECs and these generators have been very expensive to manufacture and maintain. Some WECs eliminate these problems by keeping most of the costly electrical components on-shore where they are protected from the vast marine environment and can be easily serviced. This technique is an alternative to that with grid connection by undersea cabling [4]. As another measure for improving continuous power supply, certain types (Type 1a-b, Table 1) of the WECs can also supply energy by pumping seawater into a coastal reservoir at a suitable height above the calm water level, running through a channelinto a hydropower turbine for solving the general problem of fluctuating output in wave energy [4].

Since the seas and oceans are open to the wind, they are richer in wave energy than the closed seas; further the west coasts of the continents have a higher wave energy value compared to their east coasts because of the Coriolis forces. However, it was turned out that setting up WEC plants in the open seas and oceans contains important problems regarding economic and technical aspects as above-mentioned. In conclusiondespiteany drawbacks, ones reaches suitable results if the WEC plants are deployed in coastal and/or nearshore areas in shallow waters. 


\section{"Mircea cel Batran" Naval Academy Scientific Bulletin, Volume XIX - 2016 - Issue 1 \\ Published by "Mircea cel Batran" Naval Academy Press, Constanta, Romania // The journal is indexed in: PROQUEST / DOAJ / DRJI / JOURNAL INDEX / I2OR / SCIENCE LIBRARY INDEX / Google Scholar / Crossref / \\ Academic Keys I ROAD Open Access / OAJI / Academic Resources / Scientific Indexing Services / SCIPIO Overview and Re-Classificationof the WECs of the European Marine Energy Centre Ltd.}

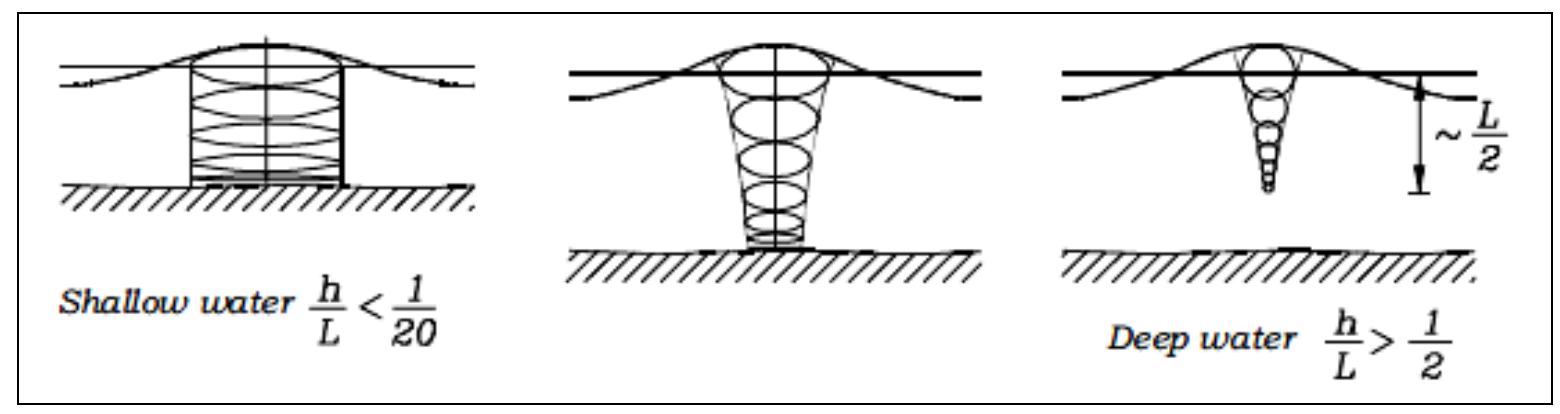

Figure 2. Movement of water molecules according to the water depth [6]

Wave energy devices convert wave energy into electricity through a power take-off system that is usually a turbine such as Pelton, Wells/HydroAir/Denniss-Auld and Kaplan turbines driven by pressurized oil, air and water, respectively. Wave energy converters can be divided into different types of classifications, e.g., The European Marine Energy Centre classifies them into nine classes $^{1}$; attenuators (A; 19\%), point absorbers $(B ; 39 \%)$, oscillating wave surge converters (C; 8\%), oscillating water column systems (D; 15\%), overtopping and terminator converters $(\mathrm{E} ; 11 \%)$, submerged pressure differential devices (F; 1,6\%), bulges (G;2\%) and rotating mass $(\mathrm{H} ; 4 \%)$ as well as the group "others" $\left(\mathrm{I} ; 0 \%^{1}\right)$ (Table 1) [5].The information on the WECs analysed in this study was obtained from original websites of each corresponding companies and the reports on their tank and/or sea tests according to the company list given by the EMEC's websiteas to $25^{\text {th }}$ March 2015. The data in Table 1 refer to the last development stages of the systems to respective time.

If all of the various concepts of the WECs registered by the EMEC should be investigated elaborately, a conclusion can be reached that the technological modelling of the EMEC is both inappropriate and non-systematic. This argumentation is proven through non- and misclassification as well as classification of the devices under the group "others" by the EMEC[5]. One of the aims of this study is to present the classification failures of the WECs of the "wave developers" prepared by the EMEC in a web-site list, which were to be reclassified and further a new classification was arranged as seen in Table 1.The other aim of the study is to assess the technological state of the art of the wave energy converters designed and/or produced for utilizing wave energy.

\footnotetext{
${ }^{1}$ The new classification in Table 1 was used.
}

\section{ASSESSMENT OF THE WAVE ENERGY CONVERTERS}

After examination of all the WECs listed by the EMEC, the following information was obtained:

i. $\quad 17 \%$ of devices could not be classified (31).

ii. $\quad 28 \%$ of converters were misclassified (51).

iii. $13 \%$ of devices were arranged under "unknowns or not-classified" (24), which should never be performed in such a classification.

This structuring needs more systematic order that can contain all various types of the WECs presented and not presented in the list of the EMEC. As initial recommendation, all the WECs designed and/or produced should principally be classified as follows (Fig. 3):

Type 1 of the WECs consisting of point absorbers, attenuators and wave surge converters as well submerged pressure differential devices defines systems generating solid body motions and/or solid body deformations using wave energy, which drive mostlyPelton turbines by a hydraulic mechanism.

Type 2 being composed of overtopping devices indicates systems creating seawater storage in a reservoir above the calm water level which drives low head (Kaplan) turbines.

Type 3 consisting of oscillating water column converters specifies systems exploiting oscillation of water columns in one or more chambers in which air columns are pressurized which drive Wells/ HydroAir /Dennis Auld turbines. In this study, these types are categorized into two subsystems: a) Systems tethered on the seafloor, b) Systems floating with the reference point of the motion, which are slack and/or taut moored to the seafloor as seen in Figure 3. 
"Mircea cel Batran" Naval Academy Scientific Bulletin, Volume XIX - 2016 - Issue 1

Published by "Mircea cel Batran" Naval Academy Press, Constanta, Romania // The journal is indexed in: PROQUEST / DOAJ / DRJI / JOURNAL INDEX / I2OR / SCIENCE LIBRARY INDEX / Google Scholar / Crossref /

Academic Keys I ROAD Open Access / OAJI / Academic Resources / Scientific Indexing Services / SCIPIO

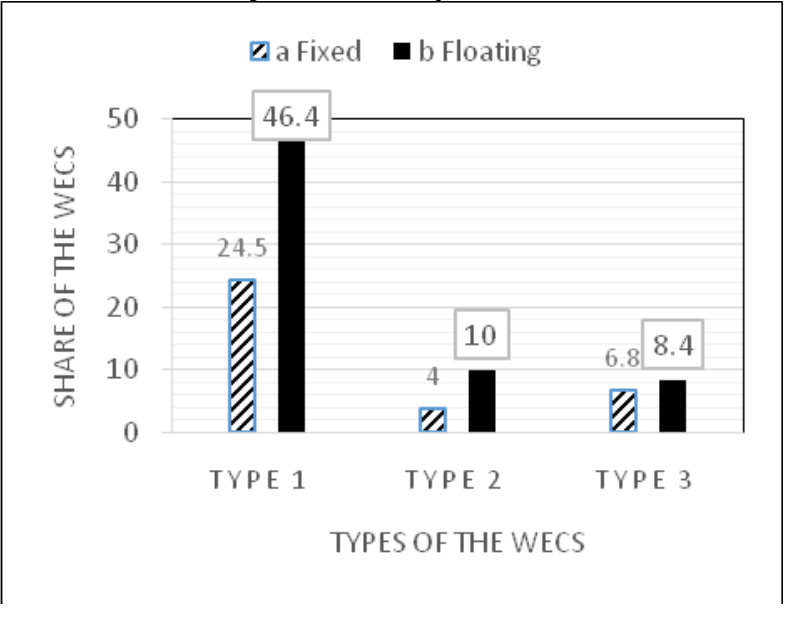

Figure 3. New classification of the WECs given by the EMEC in Table 1

As above-mentioned, wave energy, unlike wind energy far above the ground, increases the concentration at the free water surface as seen in Figure1 and 2. In the depth of one-half of the wave length in deep water the movement of water molecules does not exist. Whereas in transitional water $(1 / 2>$ Depth/Wave length $(h / L)>1 / 20)$ the movement of water molecules decreases partially to the depth, it remains unchanged in shallow water (Fig. 2). Thus, all WECs must principal be deployed as floating at or directly under the free sea surface in both deep and transitional waters; nevertheless they can be arranged at the free sea surface as well on the seabed in shallow waters.

Since formerly "most" of all devices had been very expensive in manufacturing and maintaining, large offshore WECs were designed and their prototypes were produced in order to reduce energy unit costs. Although low costs reached in energy production using these systems had provided a very big advantage, these costs increased significantly due to the offshore deployments of the WECs raising the costs of power transmission to the land and the ones of maintenance as well repair. Furthermore, it was also very difficult to protect these systems against severe storms. Therefore, it began to be designed and tested versions of the small onshore/nearshore WECs after 2000-2010. Some of those reached in pre-commercialization stage. If the Table 1 is analysed, it is seen that the projects and works have progressed in this direction. 21 of WECs were commercialised, whereas 34 of those are still in full scaled prototype testing stage. 107 WECs are undergone for small scaled prototype testing stage whilst 32 devices are still in design stage.
Since the "fixed" systems (Type 1a, 2a and 3a) are "tethered on the seafloor or onshore" generally, they have higher capacity in case of the survivalability than those of "floating system" (Type 1b, 2band 3b).For some of the both systems, additional measures have been developed "under storm conditions" such as pulling-down / up or lifting and fixing the mechanisms. However, costs of production, installation, maintenance and repair of these devices are higher than those not-having these mechanism. The taut mooring for floating systems also has the advantage of taking up less space in the sea per buoy, as opposed to slack moored buoys, and provides more energy to be harvested per square mile of sea.

Although the "fixed" devices (Type 3a) functioning according to oscillating water column principle (OWC) are costly in terms of construction and installation, they are cost-efficient regarding maintenance and repair expenditures and can better withstand heavy storms. The floating OWC devices (Type $3 b$ ) are somewhere between the fixed OWC ones (Type 3a) and the devices functioning with water weight or its pressure (Type $2 b$ ) in terms of properties above-mentioned.

In technologies of most WECs, the capacity factor is similar to the wind energy systems between 0.3 -0.40 , which amounts to be possibly larger in the southern hemisphere due to smaller seasonal variations. At the present stage of the technology development, the unit cost of electricity from wavesaveragely ranges still between wind and large photovoltaics [1].

Even in oceans where wave potential is significantly better than in open seas, the net present value of wave energy converters is still negative under current market conditions [7]. The reason for this is that the wave energy is still in its research and development phase with a few of technologies at the pre-commercial and commercial phase [8]. It can be stated that there are over 1000 wave energy conversion techniques patented in Japan, North America and Europe [2]. High capital costs coupled with low wave resources currently make wave energy conversion in the offshore and at deeper water locations of $100 \mathrm{~m}$ depth unfeasible. Generally, WEC plants being deployed in near-shore sites reduce both the cost and power losses in the cable bringing power back to shore, as well they provide considerable reduction in installation and maintenance costs [9].

A unique system in which existing offshore wind and wave technologies are combined into a single modular structure, can deliver cost-effective and competitive renewable energy system with minimal impact on the natural environment. They 


\begin{abstract}
"Mircea cel Batran" Naval Academy Scientific Bulletin, Volume XIX - 2016 - Issue 1
Published by "Mircea cel Batran" Naval Academy Press, Constanta, Romania /I The journal is indexed in: PROQUEST / DOAJ / DRJI / JOURNAL INDEX / I2OR / SCIENCE LIBRARY INDEX / Google Scholar / Crossref /

Academic Keys / ROAD Open Access / OAJI / Academic Resources / Scientific Indexing Services / SCIPIO
\end{abstract}

should be integrated into the design of nextgeneration offshore wind foundations. This technique reduces capital costs by sharing offshore infrastructure such as foundations, cabling and grid connection. Combining wave energy generation with offshore/onshore wind devices reduces the intermittency of the output power from the co-located wind-wave farm. Since this technique enables long term, sustainable cost reduction, offshore/onshore wind development can move into deeper waters, further offshore.

All types of utilizing renewable energies especially combining offshore/onshore wind energy turbines with convenient wave energy converters protrude as ideal solution which should be playing an increasingly important part in the energy landscape of industrialized nations and developing economies alike. However, delivering reliable and consistent electricity of renewable energy that can compete with conventionallygenerated electricity is still the real challenge.
Hitherto, no system of technology appears to be dominant unlike the wind energy turbines. From the technological state of the art, development and applications as well as economic trends, the conditions are similar to wind energy technologies in the 1980s. Except for a small number of cases, there is no experience of maintenance, reliability and survivability under extreme conditions in open-seas for more than one year. The most advanced technologies are still before the precommercial stage, because the design and development of a wave energy system is too complex and detailed. Only through a staged project development approach, where actual performances and operation of a device are measured and observed experimentally at a sufficiently large scale and in a sufficiently long term as well where complete system designs are developed, built and tested, both the device and its actual cost of energy can be assessed so far so precisely.

\title{
CONCLUSIONS AND FUTURE RECOMMENDATIONS
}

Hitherto, wave energy is the only renewable energy source that is not commercially exploited. Numerous designs and concepts exist and most are in early development stage with limited knowledge concerning the actual costs and expenses and/or ability to operate and survive in the harsh environment of oceans und seas.

Furthermore the systems of the WECs can be very complex in design, non-linear in performance and include numerous cost and/or legal uncertainties such as grid integration and legal processes as well permitting. In real sea conditions, predictions of numerical energy analyses on capacity factors of the WECs can be off by over $40 \%$. Until prototypes are designed, built and tested for a sufficiently long time, ones will not know the true cost of energy or not be able to reliably forecast methods of cost reduction. For the short time, the following recommendations can be mentioned:

- Caisson breakwaters for harbour protection can be combined with energy production from waves using the technology of the oscillating water column with air turbines (\%15²) and attenuators (\%39²) (Type 1 a and $3 a$ ). This is to be carried out in coastal areas of low wave energy content.

- Point absorbers and attenuators as well wave surge converters (\%66 ${ }^{2}$, Type $1 \mathrm{a}$ and $\left.1 \mathrm{~b}\right)$, which should be designed and mass-produced as simple and cost-efficient as possible, could be deployed in onshore/ near shoreby keeping most of the costly electrical components on land.

- $\quad$ The WECs above-mentioned can be utilized by pumping the seawater into a coastal reservoir at a suitable height above the calm water level, running through a channelinto a hydropower turbine.

- Further it is appropriate to build and install sufficiently large overtopping devices (\%15²) at coastal areas (Type 3a) or to deploy near shore (Type 3b), especially where the population density and industrialization level is low.

- $\quad$ For providing extensive exploitation of wave energy, large farms of the WECs should be planned as it is the case in other energy systems like wind energy.

- Combination of the WECs as much as possible with offshore/onshore wind power plants should be investigated intensively.

The traditional wave power companies are still challenging with obtaining a continuous power supply, and it seems that the existing technologies do not have the abilities to reach high energy conversion rates and therefore cannot just yet become competitive with burning fossil fuels especially at these currently low oil prices.

${ }^{2}$ Total share of the WECs in Table 1 
"Mircea cel Batran" Naval Academy Scientific Bulletin, Volume XIX - 2016 - Issue 1

Published by "Mircea cel Batran" Naval Academy Press, Constanta, Romania /I The journal is indexed in: PROQUEST / DOAJ / DRJI / JOURNAL INDEX / I2OR / SCIENCE LIBRARY INDEX / Google Scholar / Crossref / Academic Keys I ROAD Open Access / OAJI / Academic Resources / Scientific Indexing Services / SCIPIO

Table 1. WECs and company names presented by the EMEC's website as to $25^{\text {th }}$ March 2015

\begin{tabular}{|c|c|c|c|c|c|c|c|c|}
\hline Company & Device name & 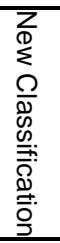 & 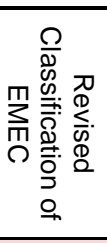 & 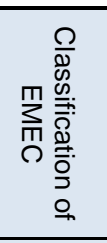 & 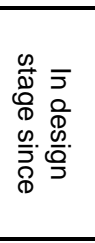 & 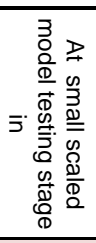 & 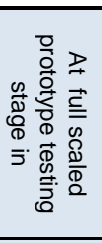 & 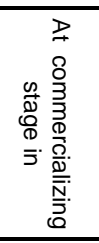 \\
\hline 40 South Energy & R115 & $1 b$ & $\mathrm{~B} / \mathrm{F} !$ & None & & & & 2013 \\
\hline Able Technologies LLC & Electric Generating Wave Pipe & $1 b$ & B & B & & 2009 & & \\
\hline AeroVironment Inc. & Eel Grass & $1 a$ & B & B & 2013 & & & \\
\hline Aker Solutions ASA & & $1 a$ & $\mathrm{~A} / \mathrm{C}$ & None & & 2014 & & \\
\hline Aker Solutions ASA & & $1 \mathrm{~b}$ & $\mathrm{~A} / \mathrm{C}$ & None & & 2014 & & \\
\hline Alba TERN & Squid & $1 b$ & B & A & & 2014 & & \\
\hline Applied Technologies Company & Float Wave Electric Power Station & $1 b$ & B & B & & 2011 & & \\
\hline Aquagen Technologies & Surge Drive & $1 a$ & $\mathrm{~B}$ & $\mathrm{~B}$ & 2011 & & & \\
\hline Aqua-Magnetics Inc. & Electric Buoy & $1 b$ & B & B & & 2012 & & \\
\hline Aquamarine Power & Oyster 800 & $1 a$ & C & C & & & 2015 & \\
\hline Atargis Energy Corporation & Cycloidal WEC (CycWEC) & $2 a$ & E! & 1 & & 2012 & & \\
\hline Avium AS & Yeti Cluster System & $1 b$ & $\mathrm{H} / \mathrm{I}$ & 1 & & & 2014 & \\
\hline Atmocean Wave Energy & Atmocean & $1 b$ & B & None & & & & 2016 \\
\hline AW Energy & WaveRoller & $1 a$ & C & C & & & 2012 & \\
\hline AWS Ocean Energy & AWS III & $3 b$ & D & $E$ & & 2011 & & \\
\hline Balkee Tide and Wave Electricity Generator & TWPEG & $1 b$ & $\mathrm{~B}$ & C/E & 2010 & & & \\
\hline BioPower Systems Pty Ltd & bioWave & $1 a$ & $\mathrm{C}$ & $C / E$ & & & 2015 & \\
\hline Blue Power Energy & & $1 a$ & B & B & & 2014 & & \\
\hline Bombora Wave Power & Bombora & $3 a$ & $\mathrm{D} !$ & $\mathrm{F}$ & & 2015 & & \\
\hline Brandl Motor & Brandl Generator & $1 b$ & B & B & 2007 & & & \\
\hline Caley Ocean Systems & Wave Plane & $2 b$ & $\mathrm{E}$ & 1 & & & 2013 & \\
\hline Carnegie Wave Energy Ltd. & CETO 5 & $1 a$ & B & B & & & 2014 & \\
\hline Checkmate Seaenergy UK Ltd. & Anaconda & $2 b$ & G & G & & 2012 & & \\
\hline College of the North Atlantic & SARAH Pump & $1 b$ & B & $\mathrm{F}$ & & 2006 & & \\
\hline Colombia Power Technologies & StingRAY & $1 b$ & $A / B$ & $A / B$ & & 2012 & & $2016 !$ \\
\hline Colombia Power Technologies & Direct Drive Rotary WEC & $1 b$ & A/B & None & & 2011 & & \\
\hline Coppe/UFRJ and TractebelEnergia & Clean Energy from Waves & $1 a$ & $A / B$ & None & & & 2012 & \\
\hline CorPower Ocean AB & $\mathrm{CPO} 2$ & $1 b$ & B & B & 2012 & & & \\
\hline Costas Wave & Costas Wave & $2 a$ & $\mathrm{E} !$ & E & & 2013 & & \\
\hline Costas Wave & Costas Wave & $2 b$ & E! & $E$ & 2013 & & & \\
\hline Daedalus Informatics Ltd. & Wave Energy Conversion Activator & $3 a$ & $\mathrm{D}$ & $\mathrm{C}$ & 2013 & & & \\
\hline Calvin College & Wave Powered Water Pump & $1 a$ & B & No data & & & 2005 & \\
\hline Del Buoy & D. B. Wave Powered Desalination & $1 b$ & B & $\mathrm{B}$ & & & & 1989 \\
\hline DEXAWAVE A/S & DEXAWAVE Convertor & $1 b$ & A & A & & 2011 & & \\
\hline Eco Wave Power & Power Wing & $1 a$ & $A !$ & 1 & & & & 2014 \\
\hline Eco Wave Power & Wave Clapper & $1 b$ & $\mathrm{~A} !$ & 1 & & & & 2014 \\
\hline EcleCentarle de Nantes & SEA REV & $1 b$ & $\mathrm{H}$ & D & & & 2010 & \\
\hline Ecomerit technologies Centipod & & $1 b$ & A & A & 2010 & & & \\
\hline Ecotricity & Searaser & $1 a$ & $\mathrm{~B}$ & B & & 2014 & & \\
\hline ELGEN Wave & Horizon Platform & $1 b$ & B & B & 2013 & & & \\
\hline Embley Energy Ltd & Sperboy & $3 b$ & $\mathrm{D}$ & $B / D$ & & 2001 & & \\
\hline Etymol Ocean Power SpA & Etymol WEC Alpha Series & $2 b$ & G & 1 & & & 2014 & 2022 \\
\hline
\end{tabular}


"Mircea cel Batran" Naval Academy Scientific Bulletin, Volume XIX - 2016 - Issue 1

Published by "Mircea cel Batran" Naval Academy Press, Constanta, Romania // The journal is indexed in: PROQUEST / DOAJ / DRJI / JOURNAL INDEX / I2OR / SCIENCE LIBRARY INDEX / Google Scholar / Crossref /

Academic Keys I ROAD Open Access / OAJI / Academic Resources / Scientific Indexing Services / SCIPIO

\begin{tabular}{|l|} 
Euro Wave Energy \\
\hline eze - Sea Power Generator \\
\hline eze - Offshore Sea Power Generator \\
\hline
\end{tabular}

Company

FlanSea

(Continued)

Float Inc

Floating Power Plant

Wave Pioneer 1

\begin{tabular}{|l}
\hline Floating Power Plant \\
\hline FOBOX AS \\
\hline Fred Olsen
\end{tabular}

\begin{tabular}{|l} 
Fred Olsen Co. G \\
\hline Fred Olsen Ltd \\
\hline Fred Olsen Ltd
\end{tabular}

Fred Olsen Ltd

Fred Olsen Ltd

G Edward Cook

G Edward Cook

GraysHarbor Ocean Energy Comp.

GasNaturalFenosa

Greencat Renewables

Greenheat Systems Ltd.

Grey Island Energy Inc.

Group Captain SM Ghouse

\begin{tabular}{l|l} 
Rho Cee & $3 b$
\end{tabular}

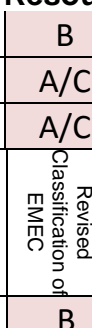

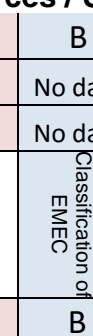

Poseidon-Wave wind hybrid $1 \mathrm{~b}$

$\begin{array}{ll}\text { FO3 } & 1 b\end{array}$

S

\begin{tabular}{l|l} 
SEEWEC & 1 \\
\hline
\end{tabular}

\begin{tabular}{|l|}
\hline Gyrodynamics Co Ltd. \\
\hline GyroWaveGen
\end{tabular}

\begin{tabular}{|l|}
\hline Hann-Ocean \\
\hline Hann-Ocean \\
\hline Havkraft
\end{tabular}

HidroFlot SA

Hydrocap Energy SAS

IHC Tidal Energy

IHC Tidal Energy

Independent Natural Resources

Indian Wave Energy Device

Innova Foundation

Intentium AS

JAMSTEC

Jospa Ltd.

(n)

\begin{tabular}{l|l}
\hline The B1 Buoy & $1 \mathrm{~b}$ \\
\hline Wavehub & $1 \mathrm{~b}$ \\
\hline BOLT Lifesaver & $1 \mathrm{~b}$
\end{tabular}

\begin{tabular}{|l|l|}
\hline$D$ & $B$ \\
\hline$A$ & $A$ \\
\hline
\end{tabular}

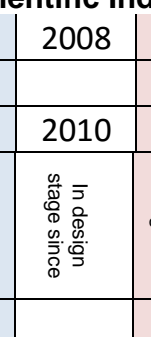

Joules Energy Efficiency Services Ltd.

Joules Energy Efficiency Services Ltd.

Kinetic Wave Power

Kneider Innovations

Korean Ins. of Ocean Science and Tech.

Korean Ins. of Ocean Science and Tech.

KN Ocean Energy Science\&Development

Laminaria

Lancaster University

Lancaster University

Lancaster University

Langlee Wave Power

Leancon Wave Energy

Limerick Wave Ltd.

\begin{tabular}{ll}
\hline BOLT Lifesaver \\
\hline Syphon Wave Genertator \\
\hline Floating Wave Genertator
\end{tabular}

Titan

\begin{tabular}{|l|l|}
\hline OWC & $3 a$ \\
\hline Wave Turbine & $1 b$
\end{tabular}

\begin{tabular}{|l|l}
\hline GentechWaTS & $1 b$ \\
\hline SeaWeed & $1 b$
\end{tabular}

FreeFloatingWEC

\begin{tabular}{l|l} 
A & A \\
\hline B & D \\
\hline
\end{tabular}

\begin{tabular}{l|l}
\hline B & B \\
\hline B & A \\
\hline
\end{tabular}

\begin{tabular}{c|c|}
\hline B & A \\
\hline B & None \\
\hline
\end{tabular}

\begin{tabular}{|c|c|}
\hline B & None \\
\hline B & None \\
\hline E & A \\
\hline A & F \\
\hline
\end{tabular}

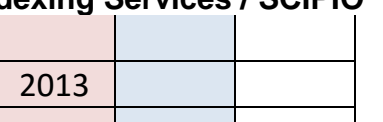

\begin{tabular}{|l|l|}
\hline & $1 b$ \\
\hline Drakoo B & $1 b$ \\
\hline
\end{tabular}

\begin{tabular}{l|}
\hline Drakoo R \\
\hline Evolver (Havkraft WEC) \\
\hline Hidroflot
\end{tabular}

\begin{tabular}{|c|c|}
\hline $2 a$ & $E$ \\
\hline $2 b$ & $E$ \\
\hline $3 a$ & $D$ \\
\hline $1 b$ & $B$ \\
\hline
\end{tabular}

Seacap

Wave Rotor (Floating)

SEADOG

IWAVE

Penwest

Intentium Offshore WEC

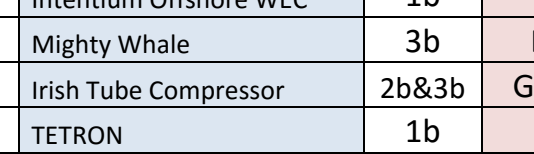

\begin{tabular}{l|l}
\hline $1 a$ & $B$ \\
\hline $2 a$ & $E !$ \\
\hline $2 b$ & $E !$
\end{tabular}

\begin{tabular}{l|l}
\hline$D$ & $D$ \\
\hline$D$ & $D$ \\
\hline
\end{tabular}

\begin{tabular}{|c|c|c|} 
A & D & A \\
\hline & A \\
\hline
\end{tabular}

\begin{tabular}{l|l} 
A & A \\
\hline D & I \\
\hline A & None
\end{tabular}

\begin{tabular}{|l|l|}
\hline & 200 \\
\hline & 201 \\
\hline & 200 \\
\hline
\end{tabular}

\begin{tabular}{|c|c|c|}
\hline 2013 & & \\
\hline 2009 & & \\
\hline
\end{tabular}

2012

\begin{tabular}{|l|l|l|}
\hline 2004 & & \\
\hline 2008 & 2009 & \\
\hline & 2014 & \\
\hline & 2012 & \\
\hline 2008 & & \\
\hline 2007 & & \\
\hline
\end{tabular}

2008

\begin{tabular}{|l|l|l|}
\hline 2004 & & \\
\hline 2008 & 2009 & \\
\hline & 2014 & \\
\hline & 2012 & \\
\hline 2008 & & \\
\hline 2007 & & \\
\hline
\end{tabular}

\begin{tabular}{|l|c|c}
\hline TETRON & 1b & B \\
\hline Wave Train & 1b & B \\
\hline PowerGin & 2b & E \\
\hline Wave Energy Propulsion & $1 b$ & A \\
\hline KIOST & $2 b$ & E \\
\hline KIOST & $1 b$ & C \\
KNSWING & $3 b$ & D \\
\hline Laminaria & $1 a$ & C \\
\hline WRASPA & $1 a$ & C \\
Seaweaver & $1 a$ & C \\
\hline PS Frog & $1 b$ & H \\
\hline Langlee System & $1 b$ & C \\
Multi Absorbing WEC & $3 b$ & D \\
\hline Seapower Platform & $1 b$ & A
\end{tabular}

414

DOI: 10.21279/1454-864X-16-I1-069

(C) 2015. This work is licensed under the Creative Commons Attribution-Noncommercial-Share Alike 4.0 License. 
"Mircea cel Batran" Naval Academy Scientific Bulletin, Volume XIX - 2016 - Issue 1

Published by "Mircea cel Batran" Naval Academy Press, Constanta, Romania // The journal is indexed in: PROQUEST / DOAJ / DRJI / JOURNAL INDEX / I2OR / SCIENCE LIBRARY INDEX / Google Scholar / Crossref / Academic Keys I ROAD Open Access / OAJI / Academic Resources / Scientific Indexing Services / SCIPIO

\begin{tabular}{|l|l|c|c|c|c|c|c|c|} 
M3 Wave LLC & DMP Device & 3a & F! & F & 2014 & & \\
\hline M4 Wave Power & M4 & $3 a$ & A & None & & 2014 & & \\
\hline Marine Energy Corporation & Wave Catcher Barge & 1b & B/I & B/I & 2013 & & & \\
\hline Marine Energy Corporation & Wave Catcher with round pontoons & $1 \mathrm{~b}$ & $\mathrm{~B} / \mathrm{I}$ & $\mathrm{B} / \mathrm{I}$ & 2012 & & & \\
\hline
\end{tabular}

\begin{tabular}{|c|c|c|c|c|c|c|c|c|}
\hline Company & $\begin{array}{l}\text { Device name } \\
\text { (Continued) }\end{array}$ & 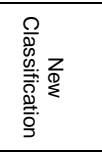 & 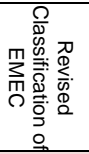 & 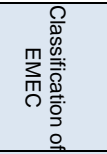 & 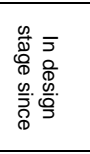 & 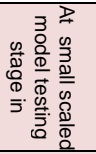 & 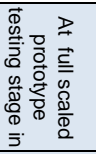 & 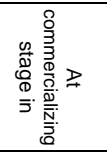 \\
\hline Marine Hydroelectric Company & & $1 a$ & B & None & & 2006 & & \\
\hline Marine Power System & WaveSub & $1 b$ & B & B & & 2014 & & \\
\hline Marine Power Tech. Pty Ltd. & Energy Island & $3 b$ & $\mathrm{D}$ & None & & 2014 & & \\
\hline MartiferEnergia & FLOW FutureLife in OceanWaves & $1 b$ & A & A & & 2010 & & \\
\hline Orecon Ltd. & MRC Orecon & $3 b$ & $\mathrm{D} !$ & No data & & & 2011 & \\
\hline Motor Wave & Motor Wave & $1 b$ & A & B & & 2006 & & \\
\hline Mururan Institute of Technology & Pendulor & $1 a$ & C & 1 & & & & For years \\
\hline Navatek Ltd. & Navatek WEC & $1 b$ & A & A & & 2007 & & \\
\hline NEMOS GmbH & NEMOS & $1 a$ & B & 1 & & 2014 & & \\
\hline Norvento & Wavecat & $2 b$ & E & None & 2008 & & & \\
\hline Norwegian University of Science a. Tech. & CONWEC & $1 a$ & B & B & & 2000 & & \\
\hline NualgiNanobiotech & Rock n Roll WE Device & $1 b$ & $A / B$ & $A / B$ & 2013 & & & \\
\hline Ocean Electric Inc. & Wave Platform & $1 b$ & B & B & 2014 & & & \\
\hline Ocean Energy Indusries Inc. & WaveSurfer & $1 b$ & B & B & & & 2012 & \\
\hline Chinese Academy of Science (GIEC) & Floating Duck & $1 b$ & A & A & & & 2012 & \\
\hline Chinese Academy of Science (GIEC) & Eagle & $1 b$ & A & A & & & 2014 & \\
\hline Ocean Energy Ltd. & Ocean Energy Buoy & $3 b$ & D & D & & 2010 & & \\
\hline Ocean Harvesting Technologies $A B$ & Ocean Harvester & $1 a$ & B & B & & 2010 & & 2016 \\
\hline Ocean Harvesting Technologies AB & Collector Hub System & $1 a$ & B & B & 2013 & & & \\
\hline Ocean Hyropower Systems Ltd. & OHS Wave Energy Array & $1 b$ & B & B & & & 2014 & \\
\hline Ocean Motion International & OMI Combined Energy System & $1 b$ & B & B & & 2013 & & \\
\hline Ocean Power Technologies & Autonomous Power Buoy & $1 a \& 1 b$ & B & B & & & 2013 & \\
\hline Ocean Rus Energy & Ocean 3 / 1607640 & $1 b$ & $\mathrm{H}$ & $\mathrm{H}$ & & & & 2013 \\
\hline Ocean Wave and Wind Energy & Wave Pump Rig & $1 b$ & B & B & & 2001 & & \\
\hline Ocean Wave and Wind Energy & OWWE Rig & $2 b$ & $E$ & $\mathrm{E}$ & 2005 & & & \\
\hline Oceanlinx & blueWAVE & $3 b$ & $\mathrm{D}$ & D & & & & 2013 \\
\hline Oceanlinx & greenWAVE & $3 a$ & D & D & & & & 2011 \\
\hline Oceanlinx & ogWAVE (Remote control app.) & $3 b \& 3 a$ & D & D & & & & 2014 \\
\hline OceantecEnergias Marinas SL & Oceantec Energy Convertor & $1 b$ & A & $\mathrm{H}$ & & 2008 & & \\
\hline Offshore Wave Energy Ltd (OWEL) & OWEL WEC & $3 b$ & D & C & & 2012 & & \\
\hline Oscilla Power Inc. & Magnetostrictive WE Harvester & $1 b$ & B & B & & & 2014 & \\
\hline OWC Power AS & OWC Power & $3 a$ & D & D & & & 2014 & \\
\hline OWC Power AS & OWC Power & $3 a$ & D & D & & & 2014 & \\
\hline OWEC Ocean Wave Energy Company & OWEC Ocean WEC & $1 a$ & B & B & & 2013 & & \\
\hline Phil Pauley Innovation & Solar Marine Cells & $1 b$ & B & 1 & 2011 & & & \\
\hline Pelagic Power AS & W2Power & $1 b$ & B & B & & 2009 & & \\
\hline Pelamis Wave Power & Pelamis & $1 b$ & A & A & & & & $2008 !$ \\
\hline PerpetuWave Power Pty Ltd. & Hybrid Float & $1 b$ & A & A & & 2013 & & \\
\hline PIPO Systems & APC-PISYS & $1 a$ & B & None & & 2012 & & \\
\hline PolyGen Ltd. & Volta WaveFlex & $1 b$ & C & C & & 2014 & & \\
\hline Pontoon Power & Pontoon Power Converter & $1 b$ & B & A & & 2012 & & \\
\hline
\end{tabular}


"Mircea cel Batran" Naval Academy Scientific Bulletin, Volume XIX - 2016 - Issue 1

Published by "Mircea cel Batran" Naval Academy Press, Constanta, Romania // The journal is indexed in: PROQUEST / DOAJ / DRJI / JOURNAL INDEX / I2OR / SCIENCE LIBRARY INDEX / Google Scholar / Crossref /

Academic Keys I ROAD Open Access / OAJI / Academic Resources / Scientific Indexing Services / SCIPIO

\begin{tabular}{|c|c|c|c|c|c|c|c|c|}
\hline Portsmounth Innovation Ltd. & WAVESTORE & $2 b$ & $E$ & $E$ & & 2012 & & \\
\hline Protean Energy Ltd. & Protean & $1 a$ & $\mathrm{~B}$ & $\mathrm{~B}$ & & 2013 & & \\
\hline Pure Marine & DUO WEC & $1 b$ & B & None & & 2012 & & \\
\hline WET-NZ New Zealand & WET-NZ Device & $1 b$ & $A / B$ & $\mathrm{~B}$ & & 2013 & & \\
\hline Purenco AS & The Fisherman WEC & $1 a$ & $B$ & $B$ & & 2011 & & \\
\hline Renewable Energy Pumps & & $1 a$ & $B$ & $\mathrm{~B}$ & 2013 & & & \\
\hline Resen Energy & Resen Waves LOPF buoys & $1 a \& 1 b$ & $B / I$ & $B / I$ & & & & 2013 \\
\hline Resolute Marine Energy Inc & SurgeWEC & $1 \mathrm{a}$ & C & $\mathrm{C}$ & & & 2013 & \\
\hline Company & $\begin{array}{l}\text { Device name } \\
\text { (Continued) }\end{array}$ & 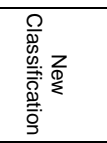 & 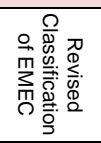 & 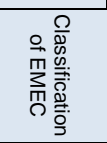 & 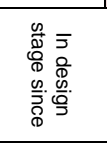 & 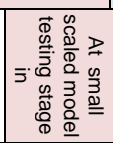 & 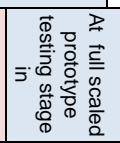 & 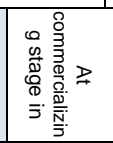 \\
\hline RTI Ocean Wave Energy & RTI Ocean WEC & $3 a$ & $\mathrm{D}$ & None & & 2013 & & \\
\hline RTI Ocean Wave Energy & RTI Ocean WEC & $3 b$ & D & None & & 2013 & & \\
\hline SARA Inc. & MHD WE Conversion & $1 \mathrm{a}$ & B & 1 & & 2008 & & \\
\hline SDE & SDE & $1 a$ & C & $\mathrm{C}$ & & & & 2010 \\
\hline Sea Carpet & & $1 a$ & $\mathrm{~F}$ & No data & & 2014 & & \\
\hline Sea Energies Ltd. & & $3 b$ & $\mathrm{D}$ & None & & 2014 & & \\
\hline Sea Power Ltd. & Sea Power Platform & $1 b$ & A & $A$ & & 2014 & & \\
\hline Sea Wave Energy Ltd (SWEL) & Waveline Magnet & $1 b$ & $A$ & I & & 2014 & & \\
\hline Seabased AB Wave Power Tech. & Linear Generator & $1 a$ & B & B & & & 2015 & \\
\hline Seamax Energy & Triton & $1 \mathrm{a}$ & $\mathrm{B}$ & 1 & & 2012 & & \\
\hline SeaNergy & Turbo Outburst Power/Top Desalination System & $1 a$ & $\mathrm{~F}$ & $\mathrm{~F}$ & & & & 2012 \\
\hline Seatricity & & $1 \mathrm{a}$ & $\mathrm{B}$ & $\mathrm{B}$ & & & 2015 & \\
\hline Seavolt & Wave Rider & $1 a$ & B & No data & 2007 & & & \\
\hline Seawood Designs Inc. & SurfPower & $1 a$ & $\mathrm{~B}$ & $\mathrm{~B}$ & & 2012 & & \\
\hline SDK Marine & SDK Marine Wave Turbine & $2 a$ & $\mathrm{E}$ & $\mathrm{D}$ & & 2014 & & \\
\hline SDK Marine & SDK Marine Wave Turbine & $2 b$ & $\mathrm{E}$ & $\mathrm{D}$ & & 2014 & & \\
\hline Sigma Energy & MD wave power converting device & $1 \mathrm{~b}$ & $\mathrm{~B}$ & None & & 2013 & & \\
\hline Snapper Consortium & Snapper & $1 a$ & B & B & & 2011 & & \\
\hline Spindrift Energy & Spindrift Energy Device & $2 b$ & $\mathrm{~B}$ & B & & 2011 & & \\
\hline SRI International & Electroactive polymer artificial muscle technology & $1 \mathrm{~b}$ & $\mathrm{~B}$ & 1 & & 2007 & & \\
\hline Tecnalia & PSE-MAR & $1 \mathrm{~b}$ & $A$ & $A$ & & 2011 & & $2013 !$ \\
\hline The CyanWave WEC & CyanWave4 & $2 b$ & $E$ & None & & 2013 & & \\
\hline Tremont Electric & nPower WEC & $1 b$ & B & B & 2011 & & & \\
\hline Trident Energy Ltd. & PowerPod Linear Generator Power & $1 b$ & $\mathrm{~B}$ & B & 2013 & & & \\
\hline University of Edinburgh & Salter's Duck & $1 b$ & $A / C$ & A & & 1980 & & \\
\hline VERT Labs & & $1 \mathrm{~b}$ & $B$ & None & & 2012 & & \\
\hline Wave Energy AS & Seawave Slot-Cone Generator & $2 a$ & $\mathrm{E}$ & $E$ & & 2007 & & \\
\hline Vigor Wave Energy $A B$ & Vigor WEC & $2 b$ & G & A & & 2014 & & \\
\hline Voith Hydro Wavegen & Limpet & $3 a$ & $\mathrm{D}$ & $\mathrm{D}$ & & & & 2000 \\
\hline Vortex Oscillation Technology Ltd. & Vortex Oscillation Technology & $2 a$ & $!$ & $\mathrm{A}$ & 2005 & & & \\
\hline Wave Dragon & Wave Dragon & $2 b$ & $E$ & $E$ & & & 2011 & \\
\hline Wave Energy Cenre (WavEC) & Pico Plant & $3 a$ & D & $\mathrm{D}$ & & & 2008 & \\
\hline Wave Energy Tech. Inc. & WET EnGen & $1 a$ & $B$ & $B$ & & 2010 & & \\
\hline Wave Energy Technology New Zealand & & $1 \mathrm{~b}$ & A/B & $\mathrm{B}$ & & 2013 & & \\
\hline Wave Star Energy ApS & Wave Star & $1 a$ & A/B! & $\mathrm{B}$ & & 2013 & & \\
\hline Waveberg Development & Waveberg & $1 b$ & A & A & & & 2012 & \\
\hline WaveBob Ltd. & WaveBob & $1 b$ & B & B & & & 2012 & \\
\hline Waveenergyfyn & Crestwing & $1 b$ & $A$ & A & & 2009 & & \\
\hline WavElectriclnc & WE 10 / WE 50 / WE 125 & $1 a \& 1 b$ & $\mathrm{~B} / \mathrm{H} !$ & $\mathrm{H}$ & & 2012 & & \\
\hline
\end{tabular}

WavElectriclnc

416

DOI: 10.21279/1454-864X-16-I1-069

(C) 2015. This work is licensed under the Creative Commons Attribution-Noncommercial-Share Alike 4.0 License. 
"Mircea cel Batran" Naval Academy Scientific Bulletin, Volume XIX - 2016 - Issue 1

Published by "Mircea cel Batran" Naval Academy Press, Constanta, Romania // The journal is indexed in: PROQUEST / DOAJ / DRJI / JOURNAL INDEX / I2OR / SCIENCE LIBRARY INDEX / Google Scholar / Crossref / Academic Keys I ROAD Open Access / OAJI / Academic Resources / Scientific Indexing Services / SCIPIO

\begin{tabular}{|c|c|c|c|c|c|c|c|}
\hline WavePiston & WavePiston & $1 b$ & $A !$ & A & & 2013 & \\
\hline WavePlane Production & WavePlane & $2 b$ & $E$ & $E$ & & 2010 & \\
\hline Waves 4 Power & WaveEL-Buoy & $1 b$ & $B$ & $\mathrm{~B}$ & & & 2012 \\
\hline Waves Ruiz & & $1 b$ & C & None & & 2014 & \\
\hline Wavetube & & $2 b$ & $\mathrm{E} / \mathrm{B}$ ! & None & & 2013 & \\
\hline Wello or & Penguin & $1 b$ & $\mathrm{H}$ & $\mathrm{H}$ & & & 2014 \\
\hline Weptos & WEPTOS WEC & $1 b$ & $\mathrm{C} / \mathrm{I}$ & 1 & & & 2015 \\
\hline Wind Waves and Sun & WaveBlanket & $3 b$ & $\mathrm{D} !$ & 1 & 2007 & & \\
\hline Yu Energy Corp. & Yu Oscillatting Generator (YOG) & $1 a$ & $\mathrm{C}$ & $\mathrm{C}$ & 2009 & & \\
\hline Yu Energy Corp. & Yu Oscillatting Generator (YOG) & $1 b$ & $\mathrm{C}$ & $\mathrm{C}$ & 2009 & & \\
\hline
\end{tabular}

\section{BIBLIOGRAPHY}

[1] Falcão AF. Developments in Wave Energy Conversion. Türkiye Offshore Energy Conference, Istanbul, 19-21 June 2013.

[2] Drew B, Plummer AR, Sahinkaya MN. A review of wave energy converter technology. Journal of Power and Energy, Proceeding of the Institute of Mechanical Engineering, Part A 2009; 223: 887-902. [2] Bahaj A. Generating electricity from the oceans. Renewable and Sustainable Energy Reviews 2011; $15: 9$ 339934160.

[3] Bernhoff H, Sjöstedt E, Leijon M. Wave energy resources in sheltered sea areas: A case study of the Baltic Sea. Renewable Energy 2006; 31: 2164-2170.

[4] Falcão AF. Wave energy utilization: A review of the technologies. Renewable and Sustainable Energy Reviews 2010; 14: 899-918.

[5] The European Marine Energy Centre. Wave energy devices 2015. http://www.emec.org.uk/wave_energy_devices.asp [accessed May 1 2015].

[6] Andersen TL, Frigaard P. Lecture Notes for the Course in Water Wave Mechanics. Aalborg University, Dept. of Civil Engineering Lecture Notes No. 16, rev. July 2011.

[7] Dalton GJ, Alcorn R, Lewis T. A 10 year installation program for wave energy in Ireland: A case study sensitivity analysis on financial returns. Renewable Energy 2012; 40: pp. 80-89.

[8] Bahaj A. Generating electricity from the oceans. Renewable and Sustainable Energy Reviews 2011; 15: 3399-3416.

[9] Folley M, Whittaker T, Henry A. The performance of a wave energy converter in shallow water. 6th European Wave and Tidal Energy Conference August 29th - September 2nd 2005, Glasgow. 